\title{
The leukemia inhibitory factor (LIF) and p21 mediate the TGF $\beta$ tumor suppressive effects in human cutaneous melanoma
}

\author{
Laure Humbert $^{1 \dagger}$, Mostafa Ghozlan ${ }^{1 \dagger}$, Lucie Canaff', Jun Tian ${ }^{1}$ and Jean-Jacques Lebrun ${ }^{1,2^{*}}$
}

\begin{abstract}
Background: Cutaneous melanoma is the most lethal skin cancer and its incidence in developed countries has dramatically increased over the past decades. Localized tumors are easily treated by surgery, but advanced melanomas lack efficient treatment and are associated with very poor outcomes. Thus, understanding the processes underlying melanoma development and progression is critical. The Transforming Growth Factor beta (TGF $\beta$ ) acts as a potent tumor suppressor in human melanoma, by inhibiting cell growth and preventing cellular migration and invasion.
\end{abstract}

Methods: In this study, we aimed at elucidating the molecular mechanisms underlying TGF $\beta$-mediated tumor suppression. Human cutaneous melanoma cell lines, derived from different patients, were used to assess for cell cycle analysis, apoptosis/caspase activity and cell migration. Techniques involved immunoblotting, immunohistochemistry, real time PCR and luciferase reporter assays.

Results: We found the leukemia inhibitory factor (LIF) to be strongly up-regulated by TGF $\beta$ in melanoma cells, defining LIF as a novel TGF $\beta$ downstream target gene in cutaneous melanoma. Interestingly, we also showed that TGF $\beta$-mediated LIF expression is required for TGF $\beta$-induced cell cycle arrest and caspase-mediated apoptosis, as well as for TGF $\beta$-mediated inhibition of cell migration. Moreover, we found that TGF $\beta$-mediated LIF expression leads to activation of transcription of the cell cycle inhibitor p21 in a STAT3-dependent manner, and further showed that p21 is required for TGF $\beta /$ LIF-mediated cell cycle arrest and TGF $\beta$-induced gene activation of several pro-apoptotic genes.

Conclusions: Together, our results define the LIF/p21 signaling cascade as a novel tumor suppressive-like pathway in melanoma, acting downstream of TGF $\beta$ to regulate cell cycle arrest and cell death, further highlight new potential therapeutic strategies for the treatment of cutaneous melanoma.

Keywords: TGF $\beta /$ Smad signaling, Tumor suppression, Cell cycle arrest, Apoptosis, p21, LIF, STAT3, Melanoma, Cell migration

\section{Background}

Skin cancer is the most common type of cancer worldwide, with an annual occurrence of almost 3 million cases. Cutaneous melanoma is one of the most aggressive and lethal human tumor, accounting for $75-80 \%$ of skin cancer-related deaths [1]. Melanoma incidence has dramatically increased over the past decades and it is now the most common cause of cancer deaths among

\footnotetext{
* Correspondence: JJ.Lebrun@mcgill.ca

${ }^{\dagger}$ Equal contributors

'Division of Medical Oncology, Department of Medicine, McGill University Health Centre, Montreal, QC, Canada

${ }^{2}$ Department of Medicine, Royal Victoria Hospital, Suite H7.66, 687 Pine Avenue West, H3A 1A1 Montreal, QC, Canada
}

young people between the age of 20-35 [2]. Melanomas have been classified into four clinical grades on the basis of their histology and prognosis. Grade IV melanomas are highly metastatic and refractory to conventional chemotherapeutic and biological reagents. Most patients have localized disease at the time of the diagnosis and are cured by surgical excision of the primary tumor, but melanomas can be highly malignant, and can metastasize to various organs including skin, lung, liver, brain and bone [2]. The fifteen-year survival for stage I melanoma is $85 \%$ whereas it is only $5 \%$ for stage IV melanoma. [1]. Melanoma display multifactorial etiology, yet its genetic and immunological background have not been elucidated. 
Thus, understanding the molecular and signaling mechanisms underlying melanoma formation and progression is a prerequisite for the development of more efficient treatments. At the molecular level, several signaling pathways have been implicated in the control of melanoma tumor formation, including the Ras-Raf-Mek-Erk cascade, which often exhibits activating mutations in cutaneous malignant melanoma [3]. Other signaling pathways potentially implicated are PI3K/AKT, Wnt, NF-kB, Jnk/c-Jun, JAK/STAT and TGF $\beta$ [4]. Contrary to frequent $B R A F$ mutations which occur at a frequency of 50-80\% [4], no genetic alterations of TGF $\beta$ signaling molecules have been identified in melanomas that could explain their resistance [5].

TGF $\beta$ signaling is initiated by the type II receptor (T $\beta R I I)$, a constitutively auto-phosphorylated serine/threonine kinase, which upon ligand binding recruits and transphosphorylates the type I receptor (T $\beta R I)$, thereby activating its kinase activity [6]. Activated T $\beta$ RI then phosphorylates mediators known as receptor-regulated Smads (R-Smads), Smad2 and 3, and allows subsequent heterotrimerization with a common partner, Smad4 $[7,8]$. The Smad heterotrimer translocates to the nucleus where it can bind DNA and regulate transcription, along with transcription factors, co-activators or co-repressors [6].

The role of TGF $\beta$ in cancer is complex and ranges from cell growth inhibition to regulation of cell migration and invasion $[6,9,10]$. In several types of cancer, such as breast cancer, TGF $\beta$ exerts a dual role: while it acts as a potent cell cycle inhibitor and a pro-apoptotic factor in normal and premalignant states, these tumor suppressive effects are lost in more advanced tumors and replaced by tumor promoting effects leading to metastasis [6,9-11]. In melanocytic systems, the role of TGF $\beta$ is different. While TGF $\beta$ acts as a potent tumor suppressor in normal melanocytes through the regulation of the plasminogen activation system, it also inhibits cell migration and cell invasion in melanoma of various stages $[12,13]$. Regarding cell growth inhibition, it has been reported that normal melanocytes in culture are sensitive to the growth-inhibitory effects of TGF $\beta$, whereas melanoma cell lines demonstrate various degrees of resistance to these effects $[14,15]$. However, TGF $\beta$ is perfectly capable of inducing Smad signaling and Smad-dependent transcription in melanomas, suggesting that desensitization to the anti-proliferative activity of TGF $\beta$ is highly specific to cell cycle progression $[12,16]$. Also, several studies have shown an increased expression and secretion of the TGF $\beta$ isoforms in melanoma cell lines compared to normal melanocytes, suggesting that TGF $\beta$ signaling is still active in these cells $[14,17-20]$. While it seems that TGF $\beta$ acts as a potent tumor suppressor in melanocytic systems, the TGF $\beta$ tumor suppressive mechanisms have not been thoroughly investigated in melanoma [21].
Previous work from our lab showed that TGF $\beta$ inhibits human cutaneous melanoma cell migration and invasion through regulation of the plasminogen activator system [12]. We found by analysis of the transcriptome of two human melanoma cell lines, WM793B (Vertical growth phase melanoma, VPG, Stage I) and WM278 (VPG, Stage II), that one particular gene, the leukemia inhibitory factor (LIF), appeared to be strongly upregulated by TGF $\beta$. Two previous studies have reported the induction of LIF mRNA and/or protein by TGF $\beta$ in Schwann cells [22] and glioblastoma [23] and shown this upregulation to be Smad-dependant by binding to a Smad binding element in LIF promoter. LIF is a member of the interleukin 6 (IL-6) family of cytokines, which includes IL-11, IL-27 and Oncostatin M (OSM) [24-26]. LIF signals through LIF receptor (LIF-R) which shares the gp130 subunit with other members of its class and which activates the JAK-STAT pathway [24-26]. LIF is expressed at the embryo stage and in many adult cell types and has been shown to be crucial for blastocyst implantation, maintenance of hematopoietic stem cells, differentiation, cell growth, inflammation, cachexia in animals, mammary gland involution after lactation, neurogenesis, and tissue regeneration $[25,26]$. Its role in cell growth is unclear as it was shown to both positively and negatively regulate proliferation [24-26], suggesting that these effects may be tissue-specific. Promotor studies and CHIP assays have shown that members of the LIF family such as Oncostatin M and IL-6 upregulate p21 expression through the Jak/STAT pathway, but this has not yet been investigated in melanoma cells $[27,28]$.

TGF $\beta$ has been shown to regulate the expression of p21, to suppress the expression of genes important for cell cycle progression and to induce the expression of genes important for senescence $[9,11]$. However, the role of p21 in apoptosis is paradoxical and more investigations are needed [29-35]. Several studies have reported that p21 was detected in primary melanomas and metastatic lesions, while p21 levels were low or undetectable in melanocytic nevi. p21 might play an important role in melanoma progression, but the mechanisms are unknown.

In the present study, we aimed to understand the molecular mechanisms underlying TGF $\beta$ growth inhibition and apoptosis in human melanoma cells.

\section{Methods \\ Reagents}

Recombinant human TGF $\beta$ and LIF were purchased from Peprotech (Dollard des Ormeaux, Quebec, Canada). Tissue culture medium RPMI1640 was from Hyclone (Logan, UT, US). FBS, antibiotics (penicillin/streptomycin) and Lipofectamine 2000 were from Life Science (Grand Island, NY, USA). Antibodies against LIF, p15, p21, c-myc, p-Stat3 (Tyr705), Stat3 and $\beta$-tubulin were from Santa 
Cruz Biotechnologies (Santa Cruz, CA, USA). Scrambled, p21 and LIF siRNAs were from Sigma (Oakville, ON, Canada). D-luciferin and Lumi-light plus were from Roche Diagnostics (Laval, Qc, Canada). MMLV reverse transcriptase and random primers were from Life Science (Grand Island, NY, USA).

\section{Cell culture}

Cutaneous melanoma cell lines WM793B and WM278 cell lines were isolated from the primary tumors of a 37-year-old male patient and a 62-year-old female patient and were kindly provided by Dr Louise Larose (McGill University, Montreal, Canada). The WM278 cell line harbors a V600E mutation in the BRAF gene, and a hemizygous deletion of PTEN. NRas and CDK4 are wild type. WM793B cells are positive for a V600E BRAF mutation and carry a W274X mutation as well as a hemizygous deletion of PTEN. This cell line also has a mutation K22Q of CDK4. NRas is wildtype.

Cells were cultured at $37^{\circ} \mathrm{C}$ in RPMI1640 medium supplemented with 10\% FBS and antibiotics under a humidified atmosphere of $5 \% \mathrm{CO}_{2}$.

\section{Cell cycle analysis}

Melanoma cells were plated in 24-well plates, serum starved overnight, and treated or not with TGF- $\beta$ (200 $\mathrm{pM}$ ) for 24 hours in a medium containing $2 \%$ FBS. Cells were washed in PBS and fixed in ethanol $70 \%$ for 2 hours. When ready for analysis, cells were resuspended in a solution containing $50 \mu \mathrm{g} / \mathrm{ml}$ propidium iodide, $50 \mu \mathrm{g} / \mathrm{ml}$ RNAse A and $0.1 \%$ Triton X-100. Cell cycle analysis was measured using an Accuri C6 flow cytometer (BD Biosciences, Mississauga, ON, Canada).

\section{Quantitative real time PCR}

Total RNAs were extracted with Trizol (Life Science, Grand Island, NY, USA) according to the manufacturer's instructions. One $\mu \mathrm{g}$ of RNA was reverse transcribed using M-MLV reverse transcriptase and random primers. Amplification of cDNA was performed by quantitative real time PCR (qPCR) (Bio-Rad iQ Sybr Green supermix, Mississauga, ON, Canada and RotorGene Corbett, San Francisco, CA, USA). Human GAPDH was used as a housekeeping gene. The qPCR conditions were: $3 \mathrm{mi}-$ nutes $95^{\circ} \mathrm{C}$, then 40 cycles of 10 seconds at $94^{\circ} \mathrm{C}, 10 \mathrm{sec}-$ onds at $60^{\circ} \mathrm{C}$ and 20 seconds at $72^{\circ} \mathrm{C}$.

\section{Immunoblotting}

Cells were lysed for 30 minutes at $4^{\circ} \mathrm{C}$ in RIPA buffer (50 mM Tris-HCL pH 7.4, $150 \mathrm{mM} \mathrm{NaCl}, 1 \%$ triton X-100, 1 mM EDTA, 1 mM EGTA, 1 mM DTT) supplemented with protease inhibitors ( $1 \mathrm{mM}$ PMSF, $10 \mu \mathrm{g} / \mathrm{ml}$ leupeptin and aprotinin and $2 \mu \mathrm{g} / \mathrm{ml}$ of pepstatin A). For analysis of phosphorylation, $100 \mathrm{mM}$ sodium fluoride,
$10 \mathrm{mM}$ sodium pyrophosphate and $100 \mathrm{mM}$ sodium ortho-vanadate were added. For analysis of LIF expression, conditioned media were concentrated using Amicon Ultra-15 Centrifugal Filter Unit with Ultracel-30 membrane (Billerica, MA, USA). Total lysates or concentrated media were immunoblotted by SDS-PAGE against specific antibodies. Immunoreactivity was revealed by chemiluminescence using Lumi-light PLUS (Roche, Mississauga, ON, Canada). Protein levels were quantified by densitometric analysis (ImageJ software, http://rsb.info. nih.gov/nih-image/).

\section{Apoptosis assay}

Melanoma cells were plated in 96-well plates, starved overnight, then treated or not for 72 hours with TGF $\beta$ (200 pM) in medium supplemented with $2 \%$ FBS. Caspase $3 / 7$ activity was measured by luminescence using Caspase 3/7 assay (Promega, Madison, WI, USA) according to the manufacturer's instructions.

\section{Promoter-reporter constructs transfection and luciferase assay}

The p21-luc and p21inr-luc constructs were kindly provided by Dr Xiao Fan Wang. For transient transfection, WM278 or WM793B cells were plated in 6-well dishes in RPMI1640, 10\% FBS (1-4 × $10^{5}$ cells per well), and incubated overnight. The next day, cells were transfected with Lipofectamine reagent with 80nM siRNA. After 24 hours cells were transfected with $1 \mu \mathrm{g}$ of promoter-reporter construct and $0.5 \mu \mathrm{g}$ of Renilla luciferase construct per well. The following day, cells were serum-starved in RPMI overnight and cultured with or without 100 pmol TGF- $\beta$ for $16 \mathrm{~h}$. Cells were washed in PBS and lysed in $250 \mu \mathrm{l}$ of passive lysis buffer ( $25 \mathrm{mM}$ glycylglycine, $15 \mathrm{mM} \mathrm{MgSO}_{4}$, $4 \mathrm{mM}$ EGTA, $1 \mathrm{mM}$ DTT and $1 \%$ Triton X-100) on ice. Supernatants were collected by centrifugation $(12,000 \mathrm{rpm}$, 20 minutes, $4^{\circ} \mathrm{C}$ ). Luciferase activity was measured in a Fluostar Optima luminometer (BMG Labtech) using $45 \mu \mathrm{l}$ of cell lysate and D-luciferin. Firefly luciferase activity was normalized to Renilla luciferase activity.

\section{Immunohistochemistry}

Tissue sections $(5 \mu \mathrm{m})$ from a melanoma microarray slide (ME1004a, US Biomax) were stained for $\mathrm{p}$-Smad3 and LIF at the Goodman Cancer Research Histology core laboratory (McGill University, Montreal, Canada). LIF staining was revealed using Bajoran purple chromogen and p-Smad3 was developed using 3,3'-Diaminobenzidine (DAB) staining. The staining was scored from 0 to 4 , where 0 means no staining while 4 means a strong staining. Representative pictures were taken at $40 \mathrm{X}$ magnification. 


\section{Migration assay}

Cells were plated on top of 24-well cell culture Transwell inserts (BD Biosciences, Mississauga, ON, Canada) and stimulated or not with TGF $\beta$ (200 pM) for 48 hours after an overnight serum starvation. The bottom chambers contained medium supplemented with $10 \%$ FBS as a chemoattractant. The migratory cells located on the filter of the bottom chamber were fixed for 10 minutes in paraformaldehyde and stained with $0.5 \%$ crystal violet. Images were taken using phase contrast light microscopy and migratory cells were counted using ImageJ software.

\section{Ethics and consent}

This study did not require any ethics statement or any written informed consent for participation from participants, as no participant, patient tissue samples but only cell lines in culture were used in the study.

\section{Results}

TGF $\beta$ induces cell cycle arrest and apoptosis in human cutaneous melanoma cell lines

We previously found TGF $\beta$ to decrease cell viability in multiple melanoma cell lines, isolated from different patients [12]. To further investigate the mechanisms by which TGF $\beta$ regulates cell growth, we analyzed its effects on both cell cycle regulation and apoptosis. First, we analyzed the cell cycle profile of two cutaneous melanoma cell lines, WM793B and WM278, treated or not with TGF $\beta$ for $24 \mathrm{~h}$. Following ethanol fixation of the cells and propidium iodide staining, the cell cycle profile was analyzed by flow cytometry. As shown in Figure 1A, WM793B and WM278 responded well to TGF $\beta$ showing a significant induction of G1 arrest. These results indicate that, while TGF $\beta$ growth inhibitory responses are lost in some melanomas, this growth factor still

A
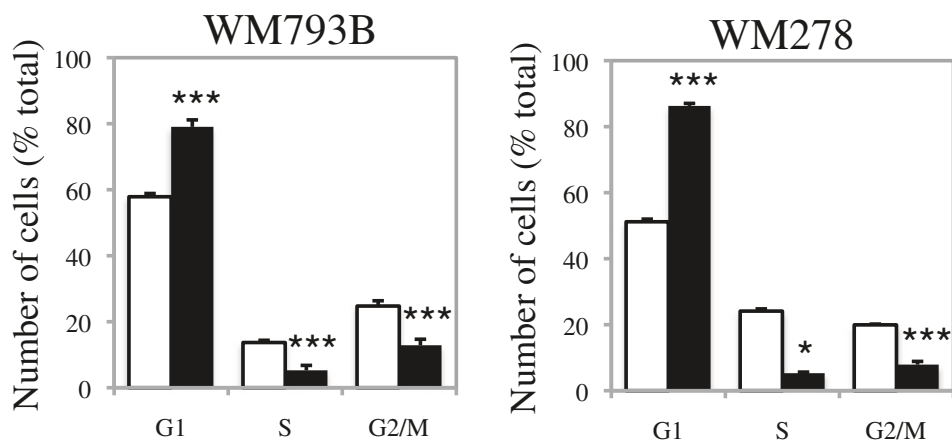

Not treated

- Treated with TGF $\beta$

B
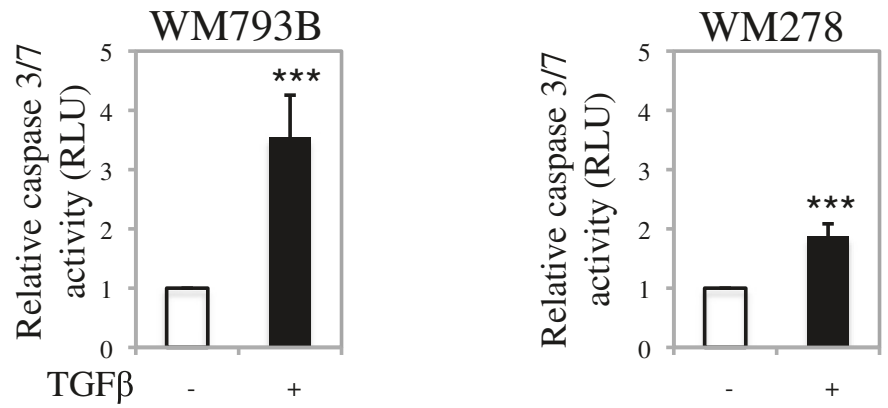

Figure 1 TGF $\beta$ exerts strong growth inhibitory effects in various cutaneous melanoma cell lines. A, WM793B and WM278 cells were treated or not with TGF $\beta$ and their cell cycle distribution was analyzed by propidium iodide staining. Data is graphed as the mean of the percentages of cells in each phase for at least 3 independent experiments. The error bars are the standard errors of the mean. For statistical analysis the $t$-test was performed compared to the non-treated control $\left(^{* * *} p<0.001,{ }^{*} p<0.05\right)$. B, WM793B and WM278 cells were treated or not with TGF $\beta$ and apoptosis was determined by measuring the caspase3/7 activity. Data is graphed as the geometric mean of relative luciferase units normalized to the non-treated control for at least 3 independent experiments. The error bars are the standard errors of the mean. For statistical analysis the z-test was performed compared to the non-treated control $\left.{ }^{* * *} \mathrm{p}<0.001\right)$. 
efficiently induces cell cycle arrest. We then analyzed the TGF $\beta$ effects on the regulation of apoptosis in these melanoma cell lines. Briefly, melanoma cells were treated or not with TGF $\beta$ for $72 \mathrm{~h}$ and caspase $3 / 7$ activity was measured using a luminescent assay. Interestingly, as shown in Figure 1B, TGF $\beta$ significantly induced cell death, indicating that it acts as a pro-apoptotic factor in human melanoma and that its tumor suppressive effects are mediated through both cell cycle arrest in the G1 phase and caspase-mediated cell death.

\section{LIF upregulation by TGF $\beta$ is required for TGF $\beta$-mediated cell cycle arrest and apoptosis}

Transcriptome analysis of WM793B and WM278 cells revealed that one particular gene, the leukemia inhibitory factor (LIF), appeared to be strongly upregulated by TGF $\beta$ (data not shown). This was further confirmed and quantified at both mRNA and protein levels. As shown in Figure 2A and B, TGF $\beta$ potently induced LIF expression both at the mRNA and protein levels in WM793B and WM278 cells, suggesting a role for LIF in mediating the TGF $\beta$ effects in melanoma cells. Both cell lines showed a 5 to 6 fold increase in protein levels, as quantified by densitometry analysis. Our results highlight LIF as a TGF $\beta$ target gene in melanoma, suggesting that it may play a role downstream of TGF $\beta$-mediated growth inhibition in melanoma. As shown in Figure 2C, while a control scrambled siRNA showed no effect, blocking LIF expression was able to almost completely block the TGF $\beta$ effect on the induction of G1 arrest, indicating that LIF plays a major role in the TGF $\beta$-induced cell cycle arrest. We then tested the effect of silencing LIF gene expression on the induction of caspase-mediated apoptosis by TGF $\beta$ in WM278 cells. As shown in Figure 2D, blocking LIF expression almost completely inhibited the TGF $\beta$-mediated induction of apoptosis, showing that LIF is required for TGF $\beta$-mediated apoptosis. Efficiency of the LIF siRNA knockdown was assessed by qPCR (Figure 2E). These results highlight the involvement of LIF in cell cycle arrest and caspase-mediated cell death upon TGF $\beta$ stimulation.

\section{TGF $\beta$ exerts its tumor suppressive effects in melanoma through regulation of the cyclin-dependent kinase inhibitor p21}

To further understand how TGF $\beta /$ LIF regulate growth inhibition in melanomas, we examined the expression levels of several cell cycle regulators that have been shown to be involved downstream of TGF $\beta$-mediated growth arrest in other tissues. These include p15 and p21 that were shown to be induced by TGF $\beta$ [36-38] and the oncogene c-MYC that was found to be downregulated by TGF $\beta$ in keratinocytes [39]. We examined the TGF $\beta$ effects on the expression levels of these downstream mediators in WM793B and WM278 cells. As observed by immunoblot analysis in Figure 3A, while there was no change in the protein expression levels of p15 or c-MYC, TGF $\beta$ significantly induced p 21 protein, suggesting that p21 may act as the main cell cycle regulator downstream of TGF $\beta$ in human melanoma. To further address the role of $\mathrm{p} 21$ in these effects, we transfected WM278 cells with a specific p21 siRNA or a scrambled sequence as a negative control and examined the TGF $\beta$ effects on cell cycle arrest. As shown in Figure 3B, TGF $\beta$ significantly induced G1 arrest in the mock and scrambled siRNA conditions. However, when p21 expression was silenced, the TGF $\beta$ effect was completely abolished, suggesting that p21 not only is required downstream of TGF $\beta$ to mediate cell cycle arrest in melanoma cells but also plays a central role in the regulation of these events. The efficiency of the p21 siRNA was demonstrated by Western blot, using a specific p21 monoclonal antibody (Figure 3C). p21 has also been linked to the apoptotic process, however its exact function remains unclear and controversial, as it was shown to inhibit apoptosis in lymphoma cells [29], primary fibroblasts [30], and hepatoma cells [31], while it promotes apoptosis in ovarian cancer cells [32], hepatocytes [33] and hepatocarcinoma cells [34], and thymocytes [35]. Thus, we investigated whether TGF $\beta$-mediated p 21 expression in melanoma cells was required for the mediation of the TGF $\beta$ pro-apoptotic effects. As shown in Figure 3D, silencing p21 expression with a specific siRNA almost completely blocked TGF $\beta$-mediated caspasemediated cell death, defining a new role for p21 in melanoma as a pro-apoptotic factor. While the mechanisms through which p21 regulates the cell cycle have been relatively well documented, its effects on apoptosis are poorly understood. In order to elucidate how $\mathrm{p} 21$ promotes apoptosis downstream of TGF $\beta$, we analyzed the expression of several pro-apoptotic genes known to be regulated by TGF $\beta$ (Bax, Bim, Bak and Apaf-1) [40]. As shown in Figure $3 E$, TGF $\beta$ induced the expression of all tested genes in melanoma cells. However, using a RNA interference approach, while we found TGF $\beta$-mediated Bax and Bim gene expression to be p21-dependent, regulation of Bak and Apaf- 1 by TGF $\beta$ does not involve p21. This indicates that p21 mediates some of the pro-apoptotic effects of TGF $\beta$ by inducing the expression of specific pro-apoptotic genes in melanoma. Together, our results highlight p21 as an important regulator of both TGF $\beta$-mediated cell cycle arrest and apoptosis in human melanoma.

\section{LIF is required for TGF $\beta$-mediated p21 upregulation}

Our results indicate that both p21 and LIF play an important regulatory role downstream of TGF $\beta$ in regulating melanoma growth inhibition. Interestingly, Oncostatin $M$, a member of the LIF family had previously been shown to 

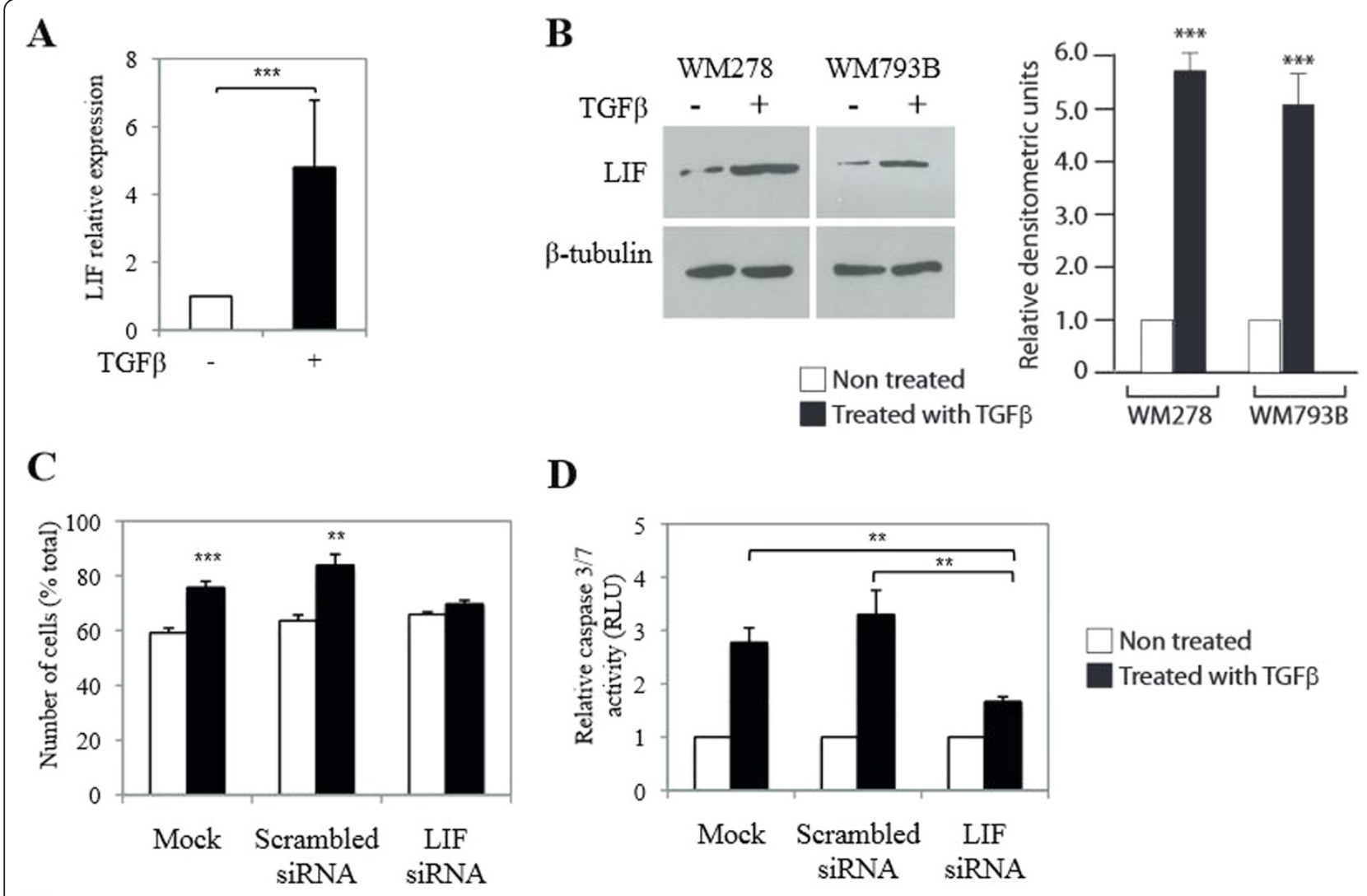

D

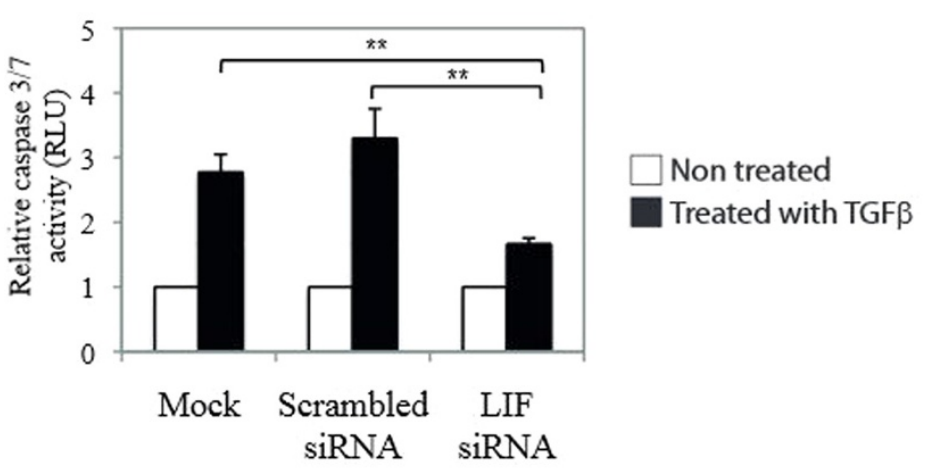

$\mathbf{E}$

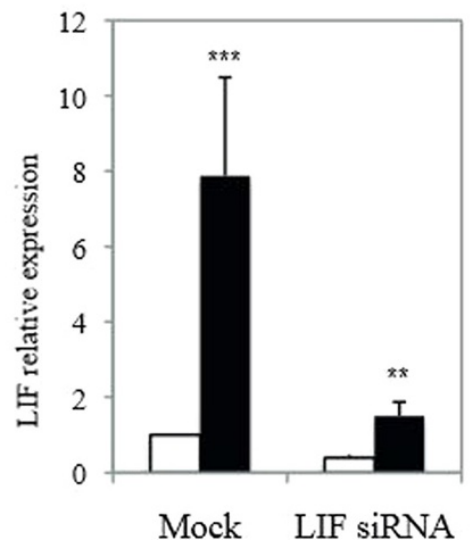

$\square$ Not treated

- Treated with TGF $\beta$

Figure 2 TGF $\beta$ mediates its effects through LIF regulation. A, WM 278 cells were treated or not with TGF $\beta$ for $24 \mathrm{~h}$ and LIF expression was analyzed by qPCR. Error bars are standard deviations and z-test was performed (*** $<0.001)$. B, WM278 and WM793B cells were treated or not with TGF $\beta$ for $24 \mathrm{~h}$ and LIF expression was analyzed by Western blot (left panel) after concentration of conditioned media. $\beta$-tubulin was used as control. Right panel: Densitometric analysis of LIF protein levels. Error bars are standard errors of mean and t-test was performed compared to non-treated control (***p 0.001$)$. C, WM278 cells transfected with scrambled or LIF siRNA $48 \mathrm{~h}$ earlier were treated or not with TGF $\beta$ for $24 \mathrm{~h}$ and apoptosis was determined by caspase $3 / 7$ activity. Error bars are standard errors of mean and z-test was performed compared to non-treated control $\left(* * p<0.01,{ }^{* *} p<0.001\right)$. D, WM278 cells transfected with scrambled or LIF siRNA $48 \mathrm{~h}$ earlier were treated or not with TGF $\beta$ for $24 \mathrm{~h}$ and apoptosis was determined by caspase3/7 activity. Data is graphed as the geometric mean of relative luciferase units normalized to non-treated control for at least 3 independent experiments. Error bars are the standard errors of mean and z-test was performed compared to non-treated control $\left({ }^{* *} \mathrm{p}<0.01\right)$. E, WM278 cells transfected with scrambled or LIF siRNA $48 \mathrm{~h}$ earlier were treated or not with TGF $\beta$ for $24 \mathrm{~h}$. LIF expression was analyzed by qPCR. Data is graphed as the mean of fold induction of gene expression in response to TGF $\beta$ for at least 3 independent experiments. Error bars are the standard errors of mean and t-test was performed compared to mock and scrambled siRNA treated conditions (**p $<0.01)$. 
A

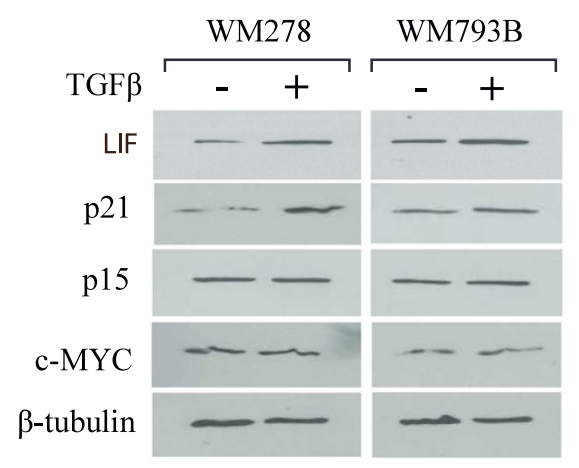

B

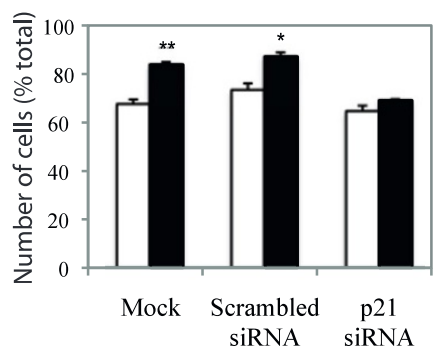

C

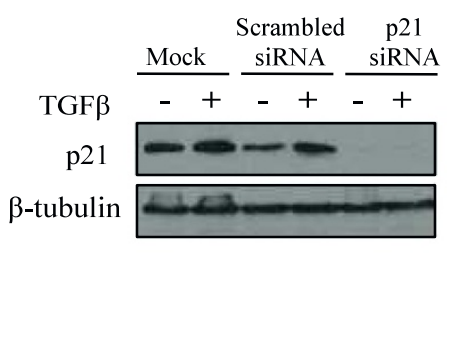

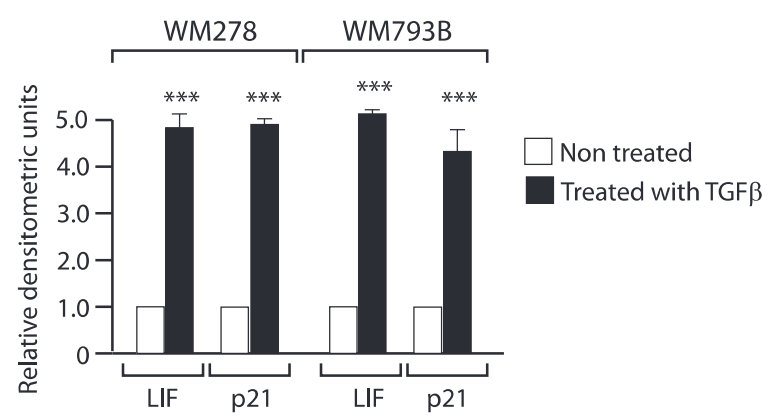

D

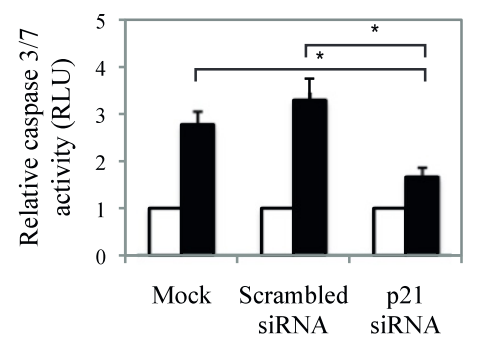

$\square$ Non treated $\square$ Treated with TGF $\beta$

E

Bax

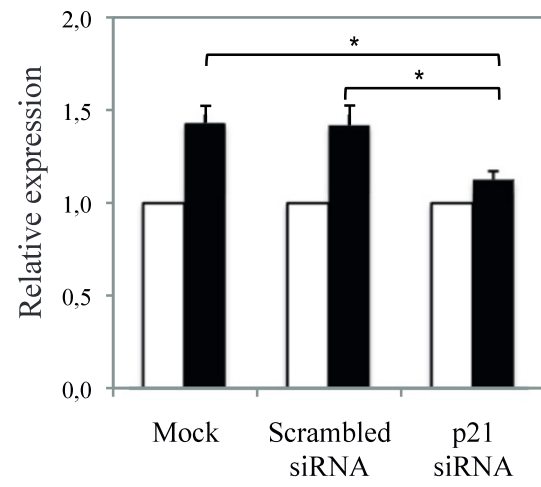

Bak

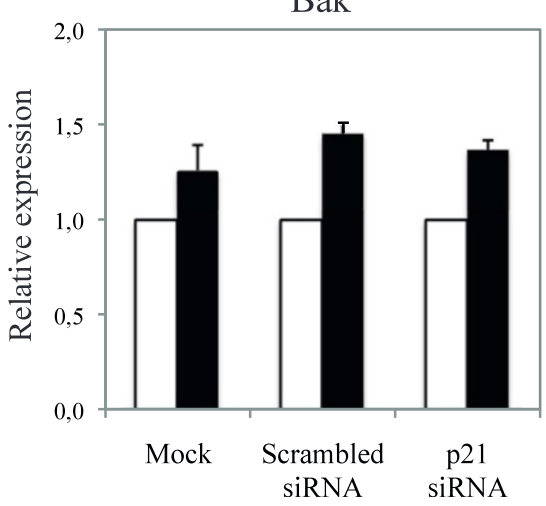

Figure $\mathbf{3}$ (See legend on next page.)

\section{Bim}

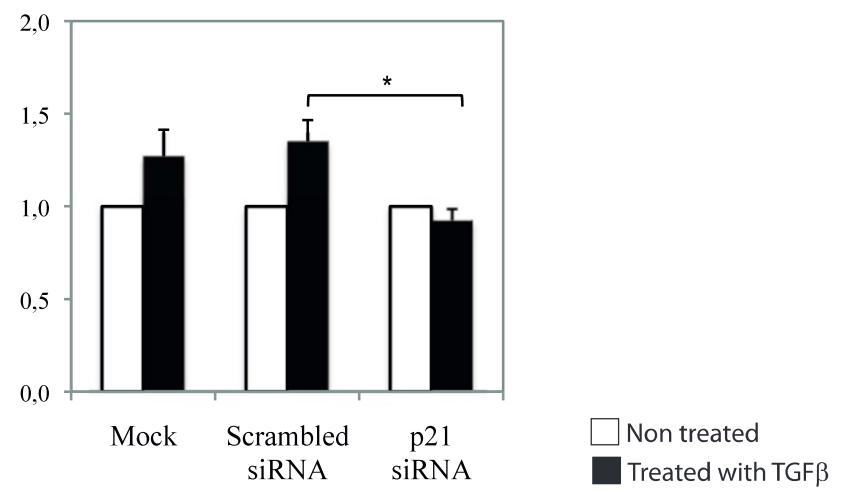

Apaf-1

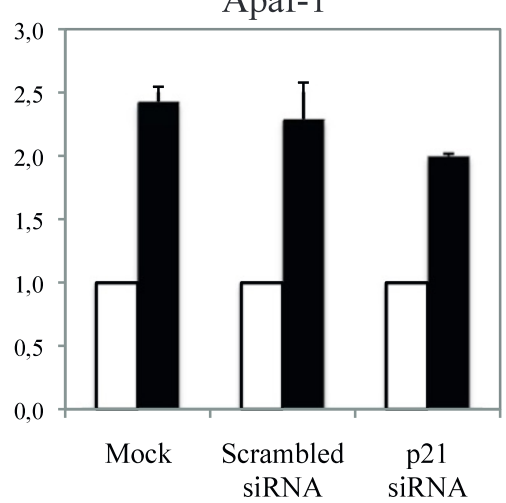


(See figure on previous page.)

Figure 3 TGF $\beta$ mediates its effects through p21 regulation. A, WM278 and WM793B were treated or not with TGF $\beta$ for 24 h and expression of LIF, p21, p15, and c-MYC was analyzed by Western blot(left panel). $\beta$-tubulin was used as control. Right panel: Densitometry of LIF and p21 protein levels. Error bars are standard errors of mean and t-test was performed compared to non-treated control $\left({ }^{* * *} p<0.001\right)$. B, WM278 cells transfected with scrambled or p21 siRNA $48 \mathrm{~h}$ earlier were treated or not with TGF $\beta$ for $24 \mathrm{~h}$ and cell cycle distribution was analyzed by propidium iodide staining. Data is graphed as mean of percentages of cells in G1 phase for 3 independent experiments. Error bars are standard errors of mean and t-test was performed compared to non-treated control $\left({ }^{* *} p<0.01,{ }^{*} p<0.05\right)$. C, WM278 cells transfected with scrambled or p21 siRNA $48 \mathrm{~h}$ earlier were treated or not with TGF $\beta$ for $24 \mathrm{~h}$ and p21 expression was analyzed by Western blot. $\beta$-tubulin was used as control. D, WM278 cells transfected with scrambled or p21 siRNA $48 \mathrm{~h}$ earlier were treated or not with TGF $\beta$ for $24 \mathrm{~h}$ and apoptosis was determined by caspase3/7 activity. Data is graphed as geometric mean of relative luciferase units normalized to non-treated control for at least 3 independent experiments. Error bars are the standard errors of mean and z-test was performed compared to non-treated control ( $\left.{ }^{*} p<0.05\right)$. E, WM278 cells transfected with scrambled or p21 siRNA $48 \mathrm{~h}$ earlier were treated or not with TGF $\beta$ for $24 \mathrm{~h}$ and gene expression was analyzed by qPCR. Data is graphed as mean of fold induction of gene expression in response to TGF $\beta$ for at least 3 replicates. Error bars are standard errors of mean and t-test was performed compared to mock and scrambled siRNA treated conditions ( ${ }^{*} p<0.05$ ).

induce p21 expression in osteoblastic cells [27,28]. This led us to investigate whether LIF could also regulate p21 gene expression, thereby linking LIF and p21 to TGF $\beta$ mediated cell growth inhibition. We first assessed the link between LIF and p21 by treating WM278 cells with LIF and showed that LIF stimulation led to p21 upregulation comparable to TGF $\beta$ treatment (Figure 4A). To then investigate whether TGF $\beta$-mediated p21 gene expression was LIF-dependent, we silenced LIF gene expression in WM278 cells and analyzed the effect of p21 regulation by TGF $\beta$ on both mRNA and protein levels. While p21 mRNA and protein expression were upregulated by TGF $\beta$ in the mock and scrambled siRNA conditions (Figure 4B and C), blocking LIF expression using a siRNA completely blocked this effect, indicating that LIF is required for TGF $\beta$-mediated p21 upregulation. Furthermore, we found this effect to take place at the transcriptional level, as LIF gene expression knockdown using a specific LIF siRNA completely blocked TGF $\beta$-induced p 21 gene promoter activity. Indeed, as shown in Figure 4D, in WM278 and WM793 cells transfected with the p21-luciferase reporter construct (p21-luc) in the presence or the absence of a scrambled or LIF specific siRNA, the TGF $\beta$-induced luciferase activity was completely blocked when LIF expression was knockdown. As LIF signaling is mediated through activation of the transcription factor STAT3, and as the p21luc construct contains a STAT3 binding element [27], we next assessed whether TGF $\beta$-induced p21 expression in melanoma was STAT3-dependent. For this, we used a second reporter construct (p21inr-luc) in which the STAT3 binding element has been removed [41]. Interestingly, TGF $\beta$ was unable to activate the p21 gene promoter in the absence of the STAT3 binding element (Figure 4D). These results indicate that LIF and its downstream effector STAT3 are required for TGF $\beta$ to induce $\mathrm{p} 21$ gene expression at the transcriptional level. STAT3 is the major effector of LIF and as shown in Figure 4E, stimulation of WM278 cells with LIF rapidly induces phosphorylation of STAT3. As we found TGF $\beta$ to increase LIF expression levels, we then investigated whether TGF $\beta$ could lead to
STAT3 activation. As shown in Figure 4F, TGFß stimulation of WM278 cells resulted in a significant increase in STAT3 phosphorylation, thus indicating that STAT3 is a downstream effector of the TFG $\beta$ pathway in these cells. Finally, to show that this increase in STAT3 activation by TGF $\beta$ was mediated through LIF, we treated WM278 and WM793B cells with LIF siRNA and treated or not with TGF $\beta$. As shown in Figure 4G, knocking down LIF blocked the phosphorylation of STAT3 by TFG $\beta$, further demonstrating that LIF is required for this regulation.

\section{LIF is required for the anti-metastatic effects of TGF $\beta$ in a p21-independent manner}

We previously showed that TGF $\beta$ is not only a tumor suppressor in cutaneous melanoma but also acts as an anti-metastatic agent, inhibiting both the migratory and invasive properties of melanoma cells [12]. Recent literature showed that LIF-R is a metastasis suppressor in breast cancer [42]. We thus investigated whether LIF signaling might also play such a role in melanoma, by regulating the TGF $\beta$-mediated inhibition of migration and invasion. We thus aimed at determining whether TGF $\beta$-mediated LIF gene expression could also mediate the TGF $\beta$ anti-migratory/invasive activities. For this, we assessed cell migration using the Transwell assay, as previously described [12]. As shown in Figure 5A, TGF $\beta$ strongly inhibited cell migration in melanoma cells. Moreover, treatment with LIF mimicked this TGF $\beta$ effect, indicating that LIF, in addition to mediate the TGF $\beta$-mediated growth inhibition, may also be involved in the TGF $\beta$ anti-metastatic effects. This was confirmed using a specific LIF siRNA: while a scrambled siRNA showed no effect, blocking LIF expression significantly inhibit the TGF $\beta$ effect on melanoma cell migration by about 60\% (Figure 5B). We then assessed if p21 had a role in this process using a specific p21 siRNA. Interestingly, blocking p21 expression had no effect on migration, indicating that LIF mediates TGF $\beta$ anti-migratory activities independently of p21 (Figure 5B). Overall these results demonstrate that LIF is not only involved in the 


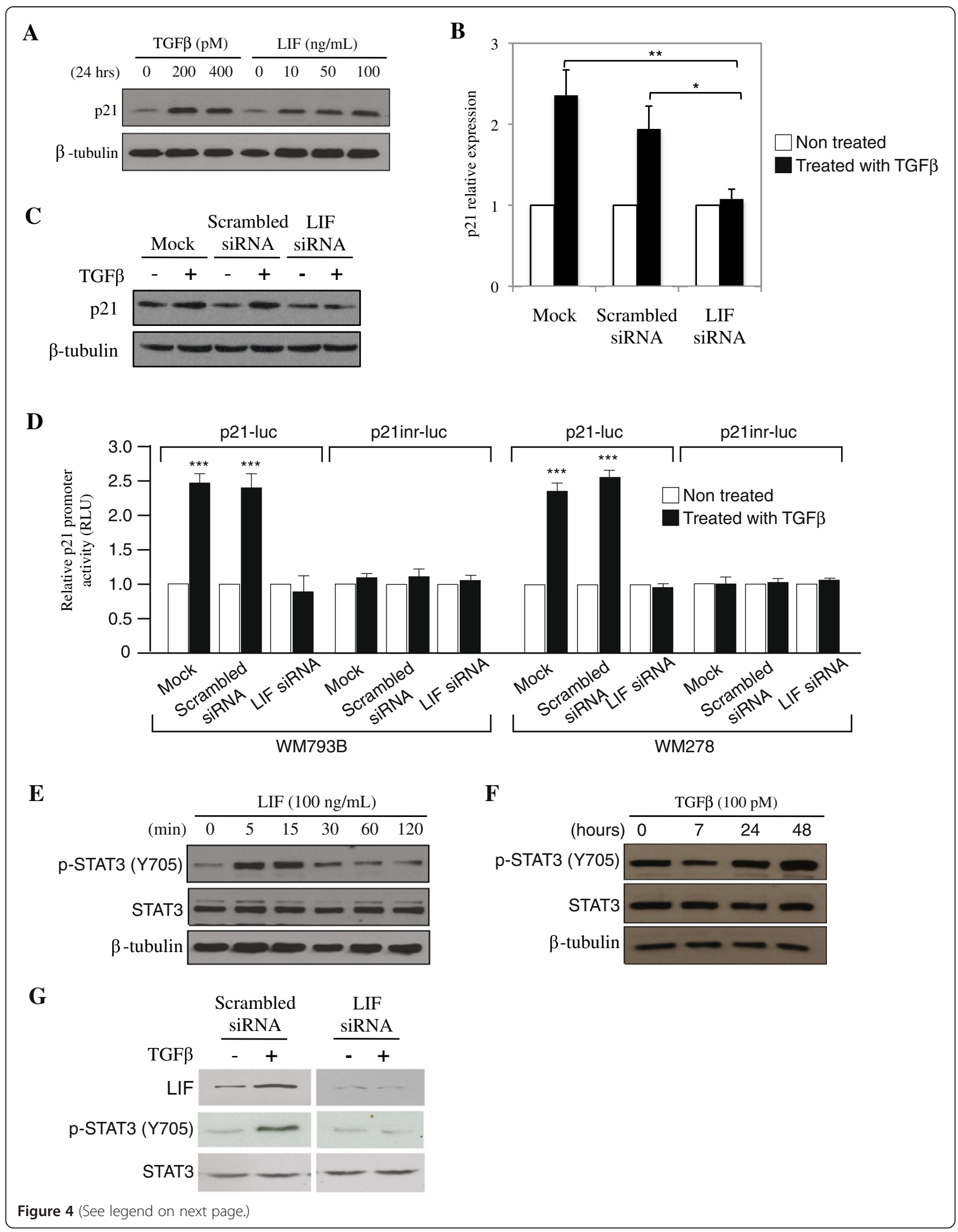




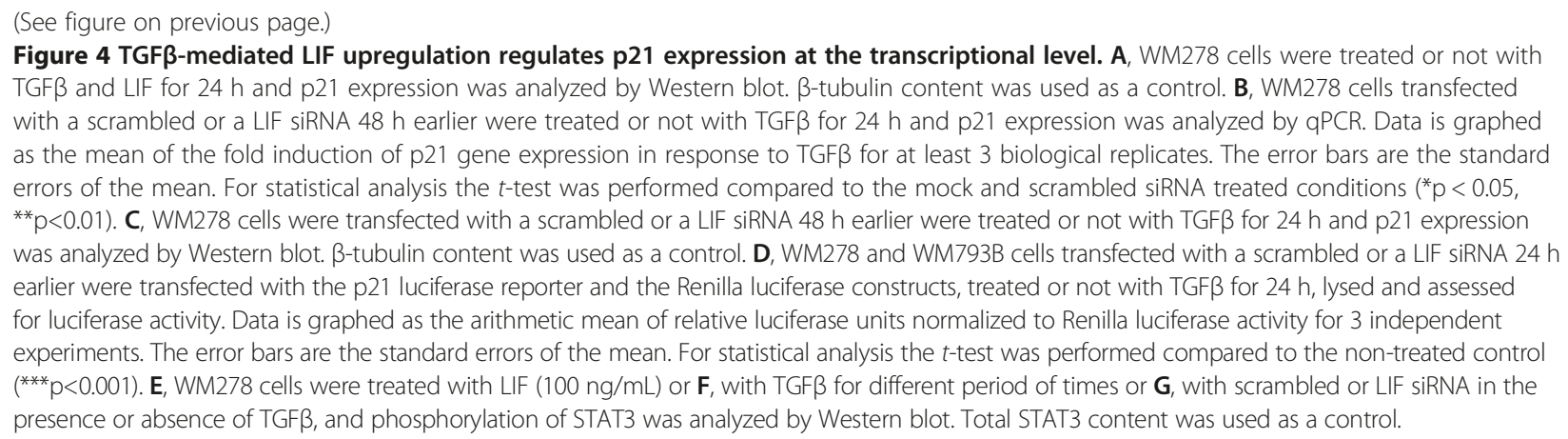

tumor suppressive effects of TGF $\beta$ but also in its antimetastatic activities, and that different pathways downstream of LIF are involved in these processes.

\section{Low response to TGF $\beta$ and low LIF expression correlate with melanoma aggressiveness}

Having highlighted the TGF $\beta /$ LIF pathway as a potent tumor suppressor in melanoma, we then assessed the clinical relevance of these findings. For this, we analyzed phospho-Smad3 and LIF expression levels by immunohistochemistry in a tissue microarray consisting of 24 benign tumors, 56 malignant tumors, and 20 metastatic melanomas. Phospho-Smad3 was measured as an indicator of TGF $\beta$ signaling activity in these tumors. As shown in Figure 6, neoplastic cells in benign tumors showed high levels of phosphorylated Smad3, indicative of high TGF $\beta$ signaling activities. However, phospho-Smad3 levels were reduced in malignant tumors and even further diminished in the metastatic tissue samples. This is consistent with previous findings showing that normal melanocytes in culture are sensitive to the growth inhibitory effects of TGF $\beta$, whereas melanoma cell lines demonstrate various degrees of resistance to TGF $\beta$ inhibitory effects, proportional to the tumor progression stage $[14,15]$. Interestingly, LIF expression levels exhibited a similar pattern, showing very high levels of expression in benign tumors, with a progressive decrease in malignant and metastatic tumors. These results indicate that while the TGF $\beta /$ LIF signaling axis acts as tumor suppressor pathway in the early stages of melanoma progression, it is partially disrupted in advanced stages, further emphasizing its essential role in the prevention of melanoma development and progression.

\section{Discussion}

As illustrated in Figure 7, in this study, we showed that TGF $\beta$ regulates cell growth in melanoma not only by acting as a cell cycle inhibitor but also as a potent inducer of caspase-mediated cell death. We further dissected the intracellular mechanisms underlying these effects and found that the leukemia inhibitory factor (LIF) plays a critical role in mediating these tumor suppressive effects. Our results define LIF as a novel target downstream of TGF $\beta$ in melanoma cell lines and indicate that TGF $\beta$-induced expression of LIF is a prerequisite for the TGF $\beta$ tumor suppressive effects, including cell cycle arrest and apoptosis as well as the inhibition of cell migration. In addition, we found that the cyclin-dependent kinase inhibitor p21 plays a significant role in mediating both G1 arrest and apoptosis, but not cell migration downstream of TGF $\beta$. Moreover, we found that TGF $\beta$ mediated p21 gene expression can induce expression of pro-apoptotic genes, such as Bax and Bim, leading to cell death. Our study defines a novel regulatory pathway mediated by the TGF $\beta / L I F / p 21$ signaling axis that controls tumor formation and tumor progression in melanoma.

The role of p21 as a cell cycle inhibitor has been well characterized in other tissues and cell types [37,43,44]. Through its amino-terminal CDK-cyclin inhibitory domain, p21 binds to both the cyclin subunit and the CDK subunit of CDK-cyclin complexes, preventing them from binding to p107, p130, and Rb, which are involved in cell cycle progression. p21 also directly inhibits DNA synthesis by disrupting DNA-polymerase binding to DNA. Nonetheless, the exact function of p21 in regulating apoptosis remains unclear and even controversial, as both pro- and anti-apoptotic p21 activities have been previously reported $[45,46]$. Many studies are indicative of an anti-apoptotic role for p21 in different target tissues. For example, p21-deficient lymphomas with a p53 deficient background showed a higher apoptotic rate than p21-proficient lymphomas, indicating a protective role for p21 against apoptosis [29]. Similarly, p21 depletion in human embryonic fibroblasts was reported to induce cell death in these cells [30]. In hepatoma cells, p21 was found to bind caspase 3, thereby preventing caspase activation and Fas-induced apoptosis [31]. In addition, p21 was also found to inhibit stress-induced apoptosis [47]. Indeed, p21 prevents stress-induced apoptosis mediated by the JNK and p38 signaling pathways by binding to and inhibiting the activity of the 


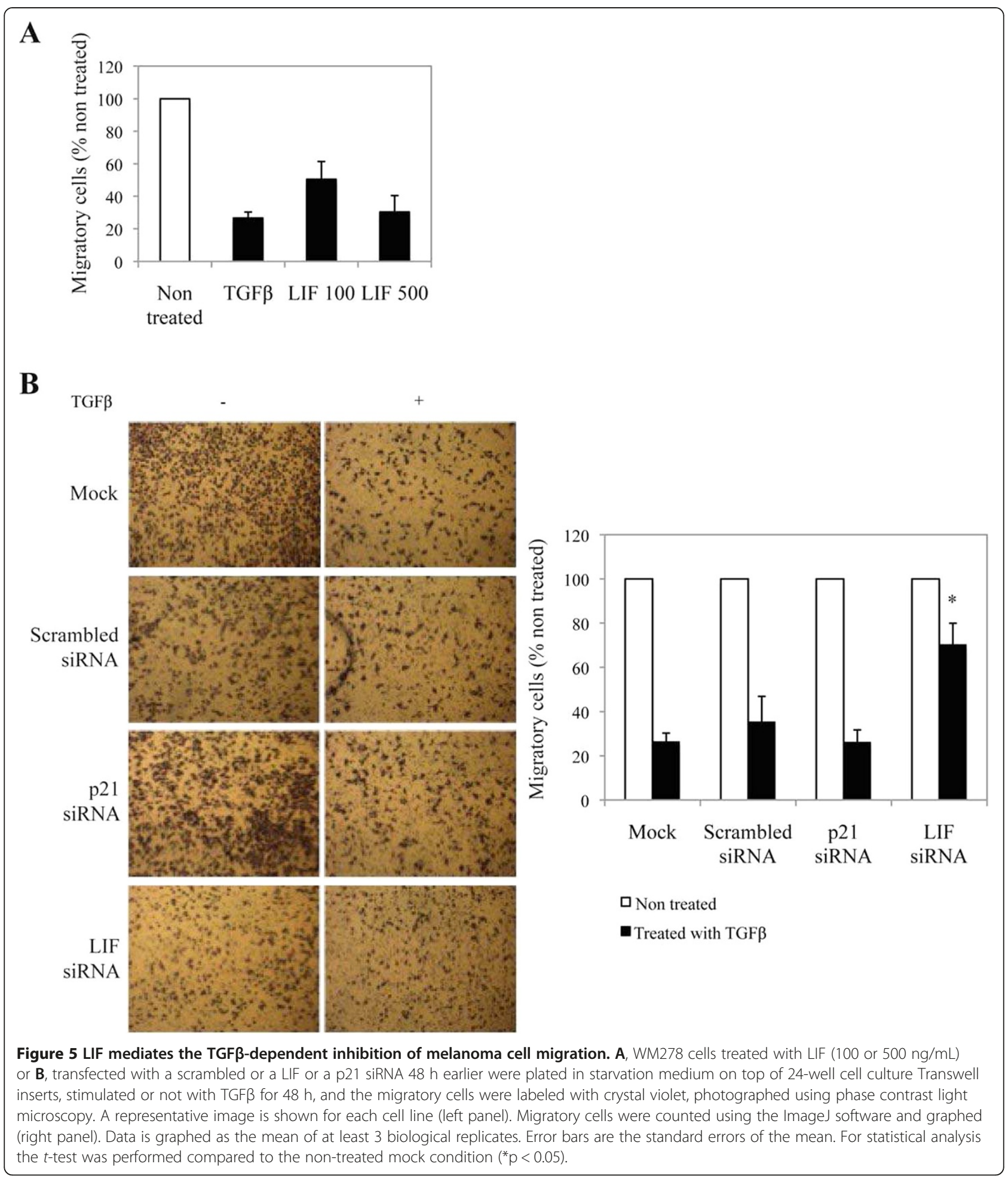

MAP3K5 (ASK1; MEKK5) in human rhabdomyosarcoma cells [48] and by binding to JNK kinases, further preventing their activation by upstream kinases [49]. On the other hand, multiple reports have also documented a pro-apoptotic role for p21. For instance, p21 overexpression in ovarian cancer cells was found to enhance susceptibility to cisplatin-induced apoptosis [32]. Reports showed that p21 could also facilitate deoxycholic acidinduced apoptosis in primary mouse hepatocytes [33] and ceramide-induced apoptosis in human hepatoma cells [34]. Similarly, thymocytes from mice carrying a p21 transgene targeted for restricted expression in the $\mathrm{T}$ 


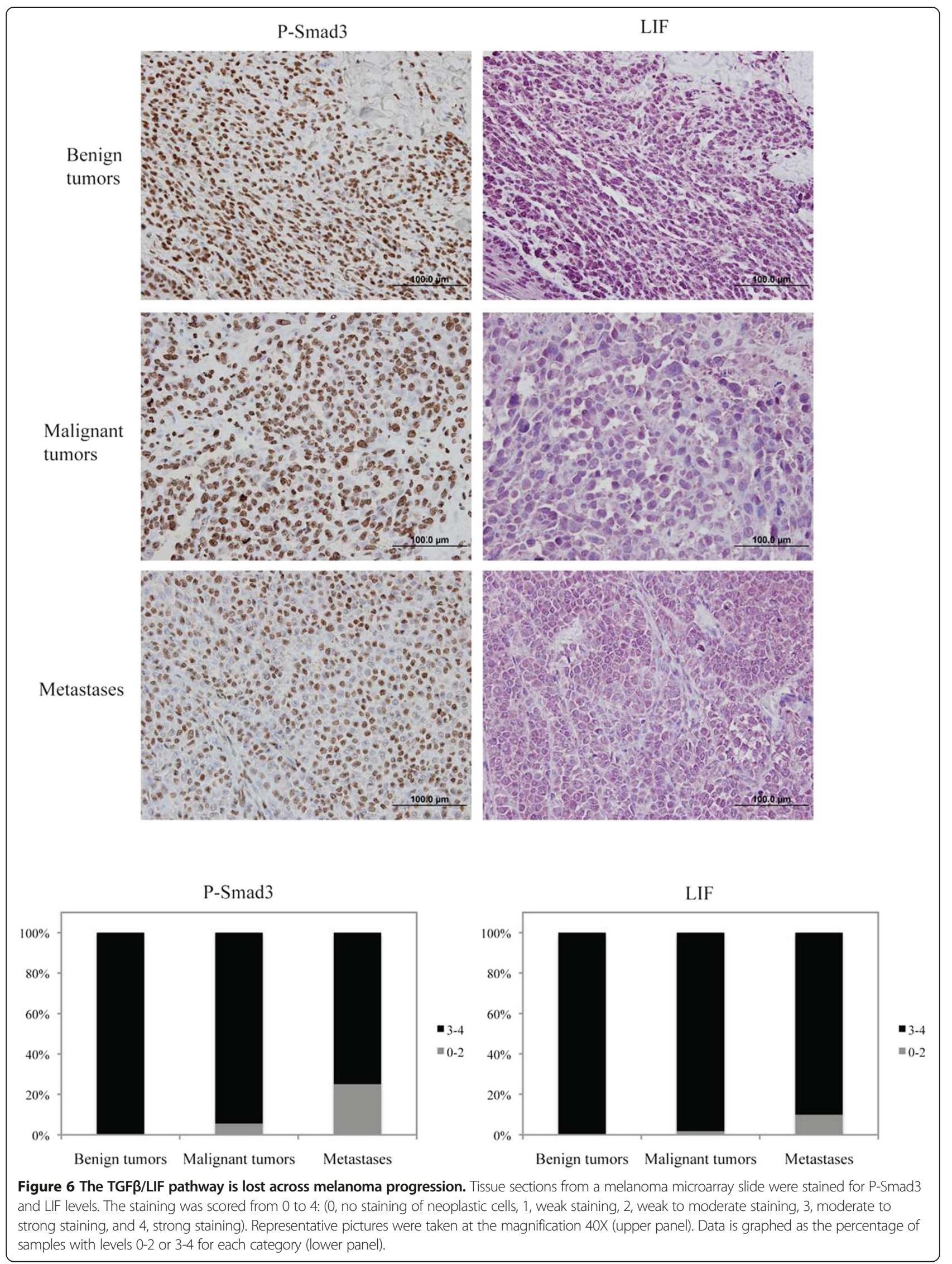




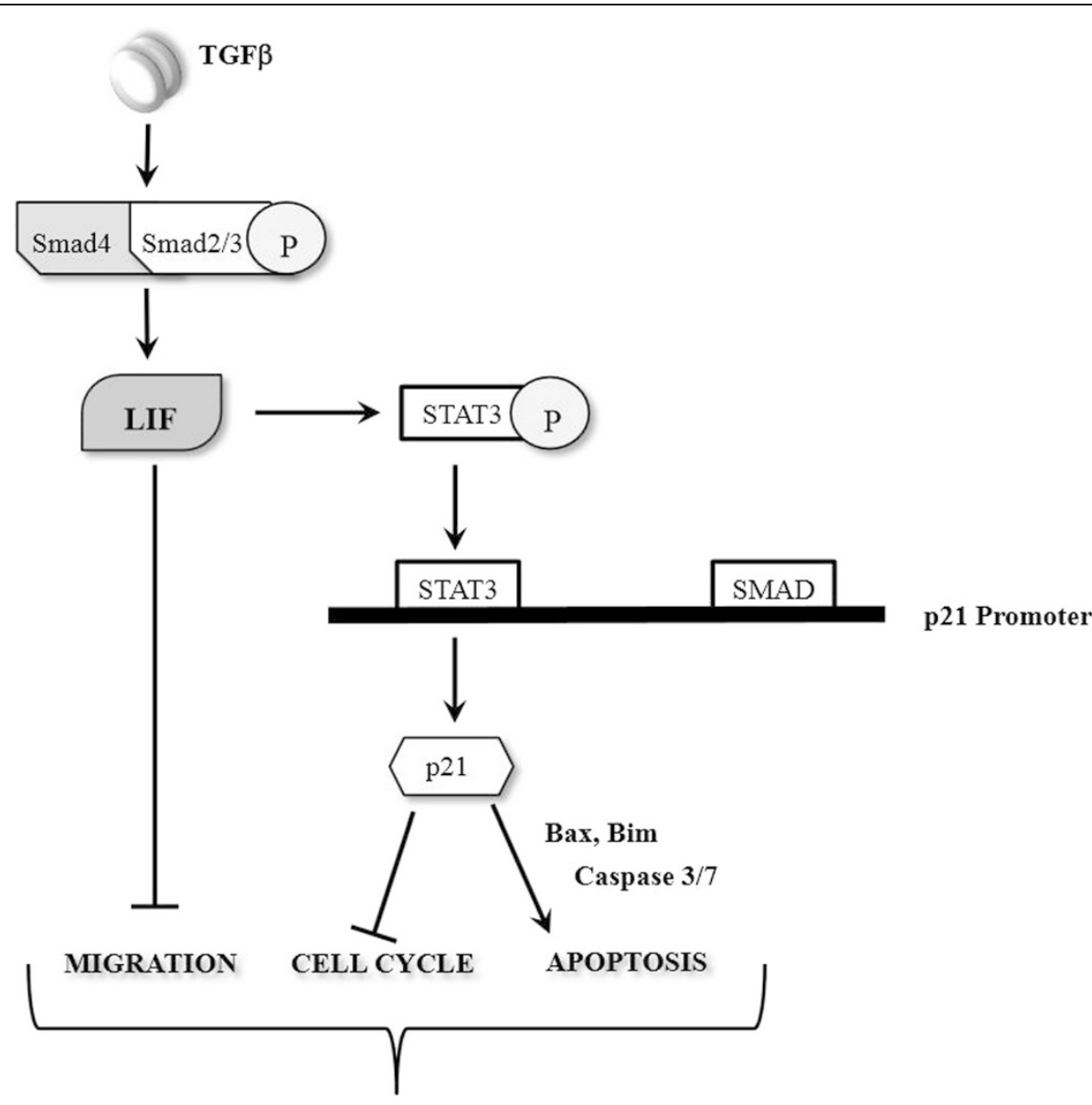

TGF $\beta$ TUMOR SUPRESSIVE ROLE IN MELANOMA

Figure 7 Schematic showing the TGF $\beta$ /LIF- mediated tumor suppressive role in melanoma. Our results show that TGF $\beta$ activates its canonical Smad signaling pathway, which in turn induces LIF secretion. LIF, via phosphorylating STAT3, triggers LIF binding to the p21 promoter, which consequently induces p21 gene expression, which elicits its inhibitory effect on cell cycle progression. Moreover, p21 induces apoptosis in a Caspase3/7 dependent manner. On the other hand, TGF $\beta$-mediated activation of LIF inhibits migratory behavior in melanoma cell lines. Taken together, these results show the TGF $\beta /$ LIF-mediated tumor suppressive role in melanoma.

cell lineage were found to be hypersensitive to radiationinduced programmed cell death [50]. These studies suggest that p21 can also act as a cell death inducer even though the molecular mechanisms underlying these effects are not fully elucidated. Altogether, these studies highlight the fact that the role of p21 in regulating cell death is clearly context-dependent. Our study indicates that, in the context of human cutaneous melanoma, p21 acts as a potent pro-apoptotic factor. We also showed that p21 acts downstream of the TGF $\beta /$ LIF signaling cascade and that it promotes caspase-dependent cell death though induced-expression of pro-apoptotic molecules, such as Bax and Bim.

Similarly, the role of LIF in cell growth regulation has not been clearly established. Evidence shows that LIF inhibits the differentiation of embryonic stem cells to maintain their pluripotentiality [51] and positively regulates the proliferation of germ cells, hematopoietic progenitors, megakaryocytes, myoblasts, and neural cells [52]. Conversely, LIF inhibits proliferation and induces differentiation of leukemic myeloid cells [53], promotes differentiation of adipocytes [54], cardiac muscle cells [55], and cardiac stem cells [56]. Exogenous LIF was reported to act as a growth factor for melanoblasts and melanocytes [57], yet another study showed that LIF did not exert any growth stimulatory effect in melanoma cells [58]. Our results clearly indicate that LIF inhibits melanoma cell growth downstream of the TGF $\beta$ signaling pathway. We found that LIF mediates both TGF $\beta$-induced G1 arrest and apoptosis in melanoma, indicating a tumor suppressor-like role for this cytokine. This is also consistent with previous reports indicating that LIF could induce G1 arrest in medullary cancer cells [59] and retinal microvascular endothelial cells [60]. In terms of cell death, 
LIF has been reported to induce apoptosis in mammary epithelial cells [61], but was found to inhibit apoptosis in other cell types, such as olfactory sensory neurons [62] and myoblast cells $[63,64]$. Thus, similar to p21, LIF function as a regulator of apoptosis appears to be cell typeand tissue-specific.

Mounting evidence show that increased nuclear pSTAT3 expression in various solid tumors, such as lung [65], breast [66], head and neck [67], as well as thyroid [68,69], is correlated with either reduced tumor size, reduced aggressiveness or enhanced survival outcomes thus pointing towards a rather tumor-suppressive role of pSTAT3 in these cancers. Our results support these findings and show that that TGF $\beta$-induced LIF expression through activation of STAT3 further leads to $\mathrm{p} 21$ gene transcription and TGF $\beta$ mediated cell cycle arrest and apoptosis in melanoma.

Moreover, our study shows that in addition to its role in mediating TGF $\beta$ tumor suppressor effects, LIF also acts downstream of TGF $\beta$ to prevent tumor progression by inhibiting cell migration, in a p21-independent manner. This indicates that LIF is a major regulator of the TGF $\beta$ effects in cutaneous melanoma, not only relaying TGF $\beta$-mediated cell cycle arrest and apoptosis but also TGF $\beta$-mediated cell migration inhibition. Thus, our results define LIF signaling as a potent tumor suppressor and as a potential suppressor of metastasis in human melanoma. In fact, this is consistent with a recent study showing that LIF receptor (LIF-R) also acts as a metastasis suppressor in breast cancer [42]. In that context, LIF-R acts downstream of the microRNA miR-9 but upstream of Hippo signaling [42]. The authors further found that loss of LIF-R expression in non-metastatic breast cancer cells induced a metastatic behavior. Consistently, we show here that LIF itself also contributes to prevention of tumor metastasis in melanoma, by mediating the TGF $\beta$ inhibitory effects on cell migration.

\section{Conclusion}

Collectively, our results indicate that the TGF $\beta / L I F / p 21$ signaling axis plays a major role in controlling tumor formation and tumor progression in melanoma. Interestingly, a recent clinical study from Tas et al., examining 60 patients with a pathologically confirmed diagnosis of melanoma, revealed that chemotherapy-responsive melanoma patients have higher levels of serum TGF $\beta$ compared to chemotherapy-refractory patients [70]. Moreover, melanoma patients with high levels of serum TGF $\beta$ also showed favorable overall survival compared to patients with lower levels [70]. These findings are in agreement with our results showing that TGF $\beta$, via LIF/STAT3 activation, leads to the suppression of the invasive phenotype in melanoma and highlight TGF $\beta$ as a favorable prognosis marker and protective growth factor against tumor metastasis in human melanoma.

\section{Competing interests}

The authors declare that they have no competing interests.

\section{Authors' contributions}

$\mathrm{LH}, M G, \mathrm{LC}$ and JT performed the experiments. LH, MG, LC and and JJL designed the study and wrote the paper. All authors read and approved the final manuscript.

\section{Acknowledgements}

The authors would like to thank Drs. A. Spatz and L. Larose for kindly providing the melanoma cell lines and Dr. X.F. Wang for providing the p21-luciferase reporter constructs. This work was supported by grants from the Canadian Institutes for Health Research (CIHR to JJL).

Received: 12 December 2014 Accepted: 6 March 2015

Published online: 29 March 2015

\section{References}

1. Balch CM, Buzaid AC, Soong SJ, Atkins MB, Cascinelli N, Coit DG, et al. Final version of the American Joint Committee on Cancer staging system for cutaneous melanoma. J Clin Oncol Official J American Soc Clin Oncol. 2001;19(16):3635-48.

2. Houghton AN, Polsky D. Focus on melanoma. Cancer Cell. 2002;2(4):275-8.

3. Davies H, Bignell GR, Cox C, Stephens P, Edkins S, Clegg S, et al. Mutations of the BRAF gene in human cancer. Nature. 2002;417(6892):949-54.

4. Lopez-Bergami P, Fitchman B, Ronai Z. Understanding signaling cascades in melanoma. Photochem Photobiol. 2008;84(2):289-306.

5. Javelaud D, Alexaki VI, Mauviel A. Transforming growth factor-beta in cutaneous melanoma. Pigment Cell Melanoma Res. 2008;21(2):123-32.

6. Humbert L, Neel JC, Lebrun JJ. Targeting TGF-beta signaling in human cancer therapy. Trends Cell Mol Biol. 2010;5:69-107.

7. Chacko BM, Qin BY, Tiwari A, Shi G, Lam S, Hayward L, et al. Structural basis of heteromeric smad protein assembly in TGF-beta signaling. Mol Cell. 2004;15(5):813-23.

8. Lebrun JJ, Takabe K, Chen Y, Vale W. Roles of pathway-specific and inhibitory Smads in activin receptor signaling. Mol Endocrinol. 1999;13(1):15-23.

9. Massague J. TGFbeta in cancer. Cell. 2008;134(2):215-30.

10. Dai M, Al-Odaini A, Arakelian A, Rabbani SA, Ali S, Lebrun JJ. A novel function for p21Cip1 and the transcriptional regulator P/CAF as critical regulators of TGFß mediated breast cancer cell migration and invasion. Breast Cancer Res. 2012;14(5):R127.

11. Lebrun JJ. The dual role of TGF in human cancer: from tumor suppression to cancer metastasis. ISRN Molecular Biol. 2012;2012:1-28.

12. Humbert L, Lebrun JJ. TGF-beta inhibits human cutaneous melanoma cell migration and invasion through regulation of the plasminogen activator system. Cell Signal. 2013;25(2):490-500.

13. Ramont L, Pasco S, Hornebeck W, Maquart FX, Monboisse JC. Transforming growth factor-beta1 inhibits tumor growth in a mouse melanoma model by down-regulating the plasminogen activation system. Exp Cell Res. 2003:291(1):1-10.

14. Rodeck U, Bossler A, Graeven U, Fox FE, Nowell PC, Knabbe C, et al. Transforming growth factor beta production and responsiveness in normal human melanocytes and melanoma cells. Cancer Res. 1994;54(2):575-81.

15. Krasagakis K, Kruger-Krasagakes S, Fimmel S, Eberle J, Tholke D, von der Ohe M, et al. Desensitization of melanoma cells to autocrine TGF-beta isoforms. J Cell Physiol. 1999;178(2):179-87.

16. Perrot $C Y$, Javelaud D, Mauviel A. Insights into the transforming growth factor-beta signaling pathway in cutaneous melanoma. Annals Dermatology. 2013:25(2):135-44.

17. Rodeck U, Nishiyama T, Mauviel A. Independent regulation of growth and SMAD-mediated transcription by transforming growth factor beta in human melanoma cells. Cancer Res. 1999;59(3):547-50.

18. Albino AP, Davis BM, Nanus DM. Induction of growth factor RNA expression in human malignant melanoma: markers of transformation. Cancer Res. 1991;51(18):4815-20.

19. Krasagakis $\mathrm{K}$, Garbe $\mathrm{C}$, Schrier PI, Orfanos CE. Paracrine and autocrine regulation of human melanocyte and melanoma cell growth by transforming growth factor beta in vitro. Anticancer Res. 1994;14(6B):2565-71.

20. Rodeck U, Melber K, Kath R, Menssen HD, Varello M, Atkinson B, et al. Constitutive expression of multiple growth factor genes by melanoma cells but not normal melanocytes. J Invest Dermatol. 1991;97(1):20-6. 
21. Lasfar A, Cohen-Solal KA. Resistance to transforming growth factor beta-mediated tumor suppression in melanoma: are multiple mechanisms in place? Carcinogenesis. 2010;31(10):1710-7.

22. Matsuoka I, Nakane A, Kurihara K. Induction of LIF-mRNA by TGF-beta 1 in Schwann cells. Brain Res. 1997;776(1-2):170-80.

23. Penuelas S, Anido J, Prieto-Sanchez RM, Folch G, Barba I, Cuartas I, et al. TGF-beta increases glioma-initiating cell self-renewal through the induction of LIF in human glioblastoma. Cancer Cell. 2009;15(4):315-27.

24. Trouillas M, Saucourt C, Guillotin B, Gauthereau X, Taupin JL, Moreau JF, et al. The LIF cytokine: towards adulthood. Eur Cytokine Netw. 2009;20(2):51-62.

25. Mathieu ME, Saucourt C, Mournetas V, Gauthereau X, Theze N, Praloran V, et al. LIF-dependent signaling: new pieces in the Lego. Stem Cell Rev. 2012;8(1):1-15

26. McKenzie RC, Szepietowski J. Cutaneous leukemia inhibitory factor and its potential role in the development of skin tumors. Dermatol Surg. 2004:30(2 Pt 2):279-90.

27. Bellido T, O'Brien CA, Roberson PK, Manolagas SC. Transcriptional activation of the p21(WAF1, CIP1, SDI1) gene by interleukin-6 type cytokines. A prerequisite for their pro-differentiating and anti-apoptotic effects on human osteoblastic cells. J Biol Chem. 1998;273(33):21137-44.

28. Halfter $H$, Friedrich $M$, Resch A, Kullmann M, Stogbauer F, Ringelstein EB, et al. Oncostatin $\mathrm{M}$ induces growth arrest by inhibition of $\mathrm{Skp2}, \mathrm{Cks} 1$, and cyclin A expression and induced p21 expression. Cancer Res. 2006;66(13):6530-9.

29. De la Cueva E, Garcia-Cao I, Herranz M, Lopez P, Garcia-Palencia P, Flores JM, et al. Tumorigenic activity of p21Waf1/Cip1 in thymic lymphoma. Oncogene. 2006;25(29):4128-32.

30. Heo Jl, Oh SJ, Kho YJ, Kim JH, Kang HJ, Park SH, et al. ERK mediates anti-apoptotic effect through phosphorylation and cytoplasmic localization of p21Waf1/Cip1/Sdi in response to DNA damage in normal human embryonic fibroblast (HEF) cells. Mol Biol Rep. 2011;38(4):2785-91.

31. Suzuki A, Tsutomi Y, Akahane K, Araki T, Miura M. Resistance to Fas-mediated apoptosis: activation of caspase 3 is regulated by cell cycle regulator p21WAF1 and IAP gene family ILP. Oncogene. 1998;17(8):931-9.

32. Lincet H, Poulain L, Remy JS, Deslandes E, Duigou F, Gauduchon P, et al. The p21(cip1/waf1) cyclin-dependent kinase inhibitor enhances the cytotoxic effect of cisplatin in human ovarian carcinoma cells. Cancer Lett. 2000;161(1):17-26.

33. Qiao L, McKinstry R, Gupta S, Gilfor D, Windle JJ, Hylemon PB, et al. Cyclin kinase inhibitor p21 potentiates bile acid-induced apoptosis in hepatocytes that is dependent on p53. Hepatology. 2002;36(1):39-48.

34. Kang KH, Kim WH, Choi KH. p21 promotes ceramide-induced apoptosis and antagonizes the antideath effect of Bcl-2 in human hepatocarcinoma cells. Exp Cell Res. 1999;253(2):403-12.

35. Hingorani R, Bi B, Dao T, Bae Y, Matsuzawa A, Crispe IN. CD95/Fas signaling in T lymphocytes induces the cell cycle control protein p21cip-1/WAF-1, which promotes apoptosis. J Immunol. 2000;164(8):4032-6.

36. Reynisdottir I, Polyak K, lavarone A, Massague J. Kip/Cip and Ink4 Cdk inhibitors cooperate to induce cell cycle arrest in response to TGF-beta. Genes Dev. 1995;9(15):1831-45.

37. Datto MB, Li Y, Panus JF, Howe DJ, Xiong Y, Wang XF. Transforming growth factor beta induces the cyclin-dependent kinase inhibitor p21 through a p53-independent mechanism. Proc Natl Acad Sci U S A. 1995;92(12):5545-9.

38. Hannon GJ, Beach D. p15INK4B is a potential effector of TGF-beta-induced cell cycle arrest. Nature. 1994;371(6494):257-61.

39. Coffey Jr RJ, Bascom CC, Sipes NJ, Graves-Deal R, Weissman BE, Moses HL. Selective inhibition of growth-related gene expression in murine keratinocytes by transforming growth factor beta. Mol Cell Biol. 1988;8(8):3088-93.

40. Korah J, Falah N, Lacerte A, Lebrun JJ. A transcriptionally active pRb-E2F1-P/CAF signaling pathway is central to TGFbeta-mediated apoptosis. Cell Death Dis. 2012;3:e407.

41. Datto MB, Yu Y, Wang XF. Functional analysis of the transforming growth factor beta responsive elements in the WAF1/Cip1/p21 promoter. J Biol Chem. 1995;270(48):28623-8.

42. Chen D, Sun $Y$, Wei $Y$, Zhang P, Rezaeian AH, Teruya-Feldstein J, et al. LIFR is a breast cancer metastasis suppressor upstream of the Hippo-YAP pathway and a prognostic marker. Nat Med. 2012;18(10):1511-7.

43. Abbas T, Dutta A. p21 in cancer: intricate networks and multiple activities. Nat Rev Cancer. 2009;9(6):400-14.
44. Romanov VS, Pospelov VA, Pospelova TV. Cyclin-dependent kinase inhibitor p21(Waf1): contemporary view on its role in senescence and oncogenesis. Biochemistry (Mosc). 2012;77(6):575-84.

45. Cazzalini O, Scovassi Al, Savio M, Stivala LA, Prosperi E. Multiple roles of the cell cycle inhibitor p21(CDKN1A) in the DNA damage response. Mutat Res. 2010;704(1-3):12-20.

46. Gartel AL. p21(WAF1/CIP1) and cancer: a shifting paradigm? Biofactors. 2009;35(2):161-4

47. Besson A, Dowdy SF, Roberts JM. CDK inhibitors: cell cycle regulators and beyond. Dev Cell. 2008;14(2):159-69.

48. Huang S, Shu L, Dilling MB, Easton J, Harwood FC, Ichijo H, et al. Sustained activation of the JNK cascade and rapamycin-induced apoptosis are suppressed by p53/p21(Cip1). Mol Cell. 2003;11(6):1491-501.

49. Shim J, Lee H, Park J, Kim H, Choi EJ. A non-enzymatic p21 protein inhibitor of stress-activated protein kinases. Nature. 1996;381(6585):804-6.

50. Fotedar R, Brickner H, Saadatmandi N, Rousselle T, Diederich L, Munshi A, et al. Effect of p21waf1/cip1 transgene on radiation induced apoptosis in T cells. Oncogene. 1999;18(24):3652-8

51. Smith AG, Nichols J, Robertson M, Rathjen PD. Differentiation inhibiting activity (DIA/LIF) and mouse development. Dev Biol. 1992;151(2):339-51.

52. Taupin JL, Pitard V, Dechanet J, Miossec V, Gualde N, Moreau JF. Leukemia inhibitory factor: part of a large ingathering family. Int Rev Immunol. 1998;16(3-4):397-426.

53. Ichikawa Y. Differentiation of a cell line of myeloid leukemia. J Cell Physiol. 1969;74(3):223-34.

54. Aubert J, Dessolin S, Belmonte N, Li M, McKenzie FR, Staccini L, et al. Leukemia inhibitory factor and its receptor promote adipocyte differentiation via the mitogen-activated protein kinase cascade. J Biol Chem. 1999;274(35):24965-72.

55. Rajasingh J, Bord E, Hamada H, Lambers E, Qin G, Losordo DW, et al. STAT3-dependent mouse embryonic stem cell differentiation into cardiomyocytes: analysis of molecular signaling and therapeutic efficacy of cardiomyocyte precommitted mES transplantation in a mouse model of myocardial infarction. Circ Res. 2007;101(9):910-8.

56. Mohri T, Fujio Y, Maeda M, Ito T, Iwakura T, Oshima Y, et al. Leukemia inhibitory factor induces endothelial differentiation in cardiac stem cells. J Biol Chem. 2006;281(10):6442-7.

57. Hirobe T. Role of leukemia inhibitory factor in the regulation of the proliferation and differentiation of neonatal mouse epidermal melanocytes in culture. J Cell Physiol. 2002;192(3):315-26.

58. Paglia D, Oran A, Lu C, Kerbel RS, Sauder DN, McKenzie RC. Expression of leukemia inhibitory factor and interleukin-11 by human melanoma cell lines: LIF, IL-6, and IL-11 are not coregulated. J Interferon Cytokine Res. 1995;15(5):455-60.

59. Arthan D, Hong SK, Park Jl. Leukemia inhibitory factor can mediate Ras/Raf/MEK/ERK-induced growth inhibitory signaling in medullary thyroid cancer cells. Cancer Lett. 2010;297(1):31-41.

60. McColm JR, Geisen P, Peterson LJ, Hartnett ME. Exogenous leukemia inhibitory factor (LIF) attenuates retinal vascularization reducing cell proliferation not apoptosis. Exp Eye Res. 2006;83(2):438-46.

61. Schere-Levy C, Buggiano V, Quaglino A, Gattelli A, Cirio MC, Piazzon I, et al, Leukemia inhibitory factor induces apoptosis of the mammary epithelial cells and participates in mouse mammary gland involution. Exp Cell Res. 2003;282(1):35-47.

62. Moon C, Liu BQ, Kim SY, Kim EJ, Park YJ, Yoo JY, et al. Leukemia inhibitory factor promotes olfactory sensory neuronal survival via phosphoinositide 3-kinase pathway activation and BCl-2. J Neurosci Res. 2009;87(5):1098-106.

63. Hunt LC, Tudor EM, White JD. Leukemia inhibitory factor-dependent increase in myoblast cell number is associated with phosphotidylinositol 3-kinase-mediated inhibition of apoptosis and not mitosis. Exp Cell Res. 2010;316(6):1002-9.

64. Hunt LC, Upadhyay A, Jazayeri JA, Tudor EM, White JD. Caspase-3, myogenic transcription factors and cell cycle inhibitors are regulated by leukemia inhibitory factor to mediate inhibition of myogenic differentiation. Skelet Muscle. 2011;1(1):17.

65. Gao SP, Mark KG, Leslie K, Pao W, Motoi N, Gerald WL, et al. Mutations in the EGFR kinase domain mediate STAT3 activation via IL-6 production in human lung adenocarcinomas. J Clin Invest. 2007;117(12):3846-56.

66. Dolled-Filhart M, Camp RL, Kowalski DP, Smith BL, Rimm DL. Tissue microarray analysis of signal transducers and activators of transcription 3 (Stat3) and phospho-Stat3 (Tyr705) in node-negative breast cancer shows 
nuclear localization is associated with a better prognosis. Clin Cancer Res. 2003;9(2):594-600.

67. Pectasides E, Egloff AM, Sasaki C, Kountourakis P, Burtness B, Fountzilas G, et al. Nuclear localization of signal transducer and activator of transcription 3 in head and neck squamous cell carcinoma is associated with a better prognosis. Clin Cancer Res. 2010;16(8):2427-34.

68. Couto JP, Daly L, Almeida A, Knauf JA, Fagin JA, Sobrinho-Simoes M, et al. STAT3 negatively regulates thyroid tumorigenesis. Proc Natl Acad Sci U S A. 2012;109(35):E2361-70

69. Kim WG, Choi HJ, Kim WB, Kim EY, Yim JH, Kim TY, et al. Basal STAT3 activities are negatively correlated with tumor size in papillary thyroid carcinomas. J Endocrinol Invest. 2012;35(4):413-8.

70. Tas F, Yasasever CT, Karabulut S, Tastekin D, Duranyildiz D. Serum transforming growth factor-beta1 levels may have predictive and prognostic roles in patients with gastric cancer. Tumour Biol. 2014. [Epub ahead of print].

\section{Submit your next manuscript to BioMed Central and take full advantage of:}

- Convenient online submission

- Thorough peer review

- No space constraints or color figure charges

- Immediate publication on acceptance

- Inclusion in PubMed, CAS, Scopus and Google Scholar

- Research which is freely available for redistribution 